\title{
Terminology as a source of misunderstanding: English and Russian humour term systems
}

\author{
Ksenia Shilikhina \\ Voronezh State University, Russia \\ shilikhina@rgph.vsu.ru
}

Ekaterina Shcheglova

Saint-Petersburg State University, Russia

e.scheglova@spbu.ru

\begin{abstract}
The field of humour studies has developed its own system of terms for designating its research objects. However, disputes about the boundaries of the concepts and their relationship within the terminological system are not uncommon. Along with the English terminological inventory there exist terminologies developed within other languages. The paper discusses key terms of humour studies in the Russian and English languages. Seven Russian terms - 'комическое', 'юмор', 'ирония', 'иутка', 'анекдот', 'насмешка,' and 'подшучивание' and six English terms - 'the comic', 'humour', 'irony', '(canned) joke', 'mocking,' and 'banter' are described. By looking at dictionary entries, definitions suggested by researchers and contexts in which the words are used as terms, the authors describe their general and terminological meanings and analyse differences of the two terminologies. Though the Russian and English terms originate from the same Greek and Latin words, there are significant differences in the traditions of their usage as scholarly terms. These differences cause difficulties which arise when it comes to translation of Russian texts into English and vice versa.
\end{abstract}

Key words: humour, terminology, translation, dictionary, equivalent.

\section{Introduction}

Terminology serves a very clear purpose - to improve performance of researchers, their internal and external communication. It facilitates unambiguous communication in a specific area of knowledge. Professional use of terms enhances the status of scholarly works and enables scientists to exchange ideas efficiently (Drame 2015). Traditionally, terminological definitions describe necessary and sufficient condition for the concept (Hacken 2015). "Knowledge modelling seeks to represent knowledge in a formal manner and aims to label items in knowledge structures unambiguously" (L'Homme 2020: 6).

Terminology is a necessary component of any science, as terms designate items of knowledge within special subject domains. Researchers develop terminologies in different ways: 
by creating new words, borrowing already existing terms from other systems of terms or borrowing words from ordinary language.

The field of humour studies has also developed its own system of terms for designating its research objects. However, unlike in many other domains of knowledge where researchers need to coin terms, the terminology for humour studies stems from general language: the concepts discussed in the field of humour studies are well-known to all language users, and the words that denote humorous phenomena have been the part of common parlance for centuries. In other words, unlike many other terminological systems, terms in the field of humour research do not constitute a realm of their own. This is the reason why disputes about the boundaries of the concepts and their relationship within the terminological system are not uncommon (see, for example, a discussion of major theories of humour and terminology used by humour researchers in Kozintsev (2007)).

Different national research traditions have developed their own understanding of key terms of humour research and formed terminologies based on their national languages. When it comes to communication at the international level, scholars speaking languages other than English find it difficult to express their thoughts and ideas using English terminology. This difficulty stems from the discrepancies between their national and English terminologies and the consequential impossibility to find precise equivalents for the terms used.

The aim of this paper is to compare terms with the semantics of humour in the Russian and English languages and contrast two terminological systems to show the differences between them. The research uses a synchronic interlingual approach, i.e. "(...) comparison of one language against another at the same point of time" (Hempelmann 2017: 35). The idea behind the comparative description of the two terminologies in this paper is to show to what degree of precision Russian and English terms can be considered translation equivalents (however, it can potentially be extended to a more general question of drawing borderlines between terms and their definitions in other languages as well).

Three types of sources of data were chosen for the research. Firstly, we analyzed definitions in general-purpose dictionaries of English and Russian to see how the meanings of words are understood by speakers of the two languages. Secondly, we consulted encyclopaedic dictionaries, the purpose of which is to present concepts (Hartmann \& James 1998). Finally, we looked at the ways researchers use the terms in their writings. It should be noted, however, that the number of publications in the field of humour research is so large that only a small number of books and research papers were selected for the analysis. Taken together, these three types of sources allowed us to see the differences between the "naïve" understanding of the word meanings and the professional use of these words as terms designating specific items of knowledge.

The paper is structured in the following way: firstly, it presents a short overview of the existing research of humour terminology. Secondly, English terms the comic, humour, irony, and (canned) joke are presented and analysed as elements of the general vocabulary and as members of the professional terminological inventory. Next, Russian explanatory dictionaries, scholarly definitions and publications are analysed with the aim of presenting the Russian terms комический (the сотіс), юмор (hитоиr), ирония (irony), шутка (joke), and анекдот (canned joke). Finally, a comparison of the two parts of terminological inventories is made to demonstrate both the equivalent and, most importantly, non-equivalent parts of these systems.

\section{An overview of existing studies}

In this overview, we will briefly look at existing approaches to the analysis of terms in general and humour terminology in particular. 
Terms are important carriers of meaning. The use of terms in the global context affects the practical issues of translation and intercultural communication, localization, language policy etc. This explains why a lot of time and effort is invested in research and systematisation of terminology.

Linguistic analysis of terms and their description in dictionaries traditionally focuses on the relationships between terms: "When analysing the meaning of terms that form the lexical structure in a field of knowledge, terminographers may be interested in various types of relationships. Any or all of these relationships may be pertinent in a given domain, and understanding them is fundamental to concept analysis and the construction of domain knowledge structures" (L’Homme \& Marshman 2006: 68).

The best way to fully explain the terminological meaning of a word is to look at its place in the terminological system (Ruch 2007). Humour scholars have been discussing the meaning of the core terms for decades; however, in most cases, researchers focus their attention on just one or two terms, trying to draw a conceptual border between them. However useful, these attempts do not present a systematic description of the whole system of terms.

A number of recent attempts to analyse English terminology of humour studies in a more systematic way should be mentioned here.

Published in 2014, The Encyclopedia of Humor Studies is the most comprehensive compendium of concepts and terms which are used in modern humour research. This book is a sign that humour research as a field of knowledge is not a "new field of research"; rather, it is a mature area of studies. However, as the readers start to familiarize themselves with the terms, they find out how difficult it is for humour scholars to define the terms they have been using for decades (if not for centuries). In his Introduction to The Encyclopedia of Humor Studies, Salvatore Attardo rightfully states that

Humor appears to be so simple, so easy. Surely it can be defined and explained in a few well-chosen sentences (...). Inevitably the old saying by Elwyn B. White, among whose works include Charlotte's Web and, with William Strunk Jr., The Elements of Style, about dissecting humor and a frog, and the frog dying under dissection much like the humor, gets trotted out to ridicule the endeavor. The problem with that view, however, is that if one asks those sceptical about humor studies to provide their definition and explanation of humor, the results are hopelessly naïve, open to refutation from several sides, and, at best, partial and incomplete.

(Attardo 2014: XXX)

The same kind of comments can be found in the entries for irony and jokes (see below). The fact that humour scholars recognize deficiencies in their own terminology infrastructure is a sign that the first step has been made on a long way to the much-needed standardization of terminology.

Hempelmann and Gironzetti use structuralist approach for the systemic analysis of the lexical field LAUGH (Hempelmann \& Gironzetti 2015). They describe paradigmatic relations between the series of words which constitute the lexical field in typologically different languages. By analysing translations of Kesey's novel One Flew over the Cuckoo's Nest, they present visual models of how different languages verbalize the conception of laughter and what semantic features are relevant for language speakers when they make a choice from a range of lemmata. The analysis results in hierarchical matrices of semantic features, with vocalization being the top of the hierarchy. Other features include aggressiveness on the part of the speaker, loudness and pitch. The idea behind this hierarchy is that it can be used for the evaluation of the accuracy of translation (Hempelmann \& Gironzetti 2015).

Another attempt of multifaceted analysis of terminology is presented in (Hempelmann 2017). Three ways of comparing terms are presented: etymological, comparison of two competing words and cross-linguistic analysis of the terms belonging to the field LAUGH. These 
approaches allow researchers to see historic development of terminology, its systematisation and its language-specific properties. Etymological analysis shows how the Latin word humor got its present meaning in many European languages. To illustrate intralanguage and cross-language comparisons of terms, Hempelmann addresses a number of earlier publications devoted to the functioning of related terms in the English, German, Spanish, and Turkish languages.

Among Russian publications, a book Human and Laughter by Kozintsev should be mentioned (Kozintsev 2007). The book continues the long-standing tradition of analysing humour from the aesthetic perspective. The author makes an attempt to explain the difference between the comic, humour and irony by criticizing linguistic and cognitive approaches to these phenomena and suggesting aesthetic criteria for the rather informal delimitation of concepts.

Researchers recognise difficulties which arise when it comes to giving precise definitions of humour terms. But the need for shared understanding of terminology exists. In an attempt to present a more systematic view of the problem, in the next section we will analyse the use of the English terms the comic, humour, irony, (canned) joke, mock(ing), and banter. As has already been mentioned, we will analyse two types of their definitions - general and encyclopaedic - and their use in professional texts written by various humour scholars.

\section{English humour terms}

\subsection{The comic}

For our further purpose of comparing English and Russian terms, we will start our discussion with the word comic - the term which is not very popular among researchers who use English in their writings. Today, its terminological usage is limited to a specific domain of knowledge theory and history of literature. Still, we feel that it is necessary to address the term here, since it is a cognate term for the Russian комическое which will be discussed below.

Dictionaries define the noun comic as "an entertainer who tells jokes in order to make people laugh" or as "a magazine that contains stories told in pictures". The adjective comic means either something that "makes you laugh, and is often intended to make you laugh" or "Comic is used to describe comedy as a form of entertainment, and the actors and entertainers who perform it" (Collins English Dictionary 2020). Interestingly, the word humour is not used in any of these definitions; but, in any case, the word comic in everyday parlance is closely connected with laughter as a reaction to something or someone being funny and laughable.

There is not much to be said about the comic as a term: the nominalized adjective is not listed in dictionaries, nor is it included in encyclopedias. Perhaps the only example is the entry for Bergson's Theory of the Comic in The Encyclopedia of Humor Studies. The entry presents the analysis of Bergson's ideas about the comic as "the essence of comedy", social functions of laughter and comic devices (Attardo 2014: 78).

Bergson's approach to the comic is a good example of a traditional use of the term in the domain of theory and history of literature. The term originated in aesthetics and was used to designate anything that refers to comedy and laughter. Humour as a concept or a term accompanied the comic on rare occasions. The comic mostly described properties of comedies as texts. No wonder that " (...) literary theorists insist that humor and the comic be kept distinct, the latter being properly applied to theatrical comedy" (Attardo 2004: XXXI).

The tradition to use the comic for the purposes of text analysis still exists. Here are some examples that illustrate the use of the term by modern literary theorists:

The perception of the comic is the perception of something that falls out of an overall order of things. Or again, to say that something is incongruous implies a notion of congruity. Thus, the perception of 
the comic depends upon (if you will, is parasitical upon) the basic human urge to order reality. Comic laughter is, so to speak, the philosophical instinct in a lower key.

(Berger 2014: 32)

The term appears in the discussions of the phenomenon of laughter. Roston states that "Critical investigation of that theme has, in fact, reached a deadlock. Robin Haig, after examining over 100 theories of the comic, concludes that not one has proved satisfactory; John Morreall opens his study with the categorical statement, '(...) we are still without an adequate general theory of laughter', while psychologists have extended that negative view by declaring that so complex a mode can never be defined (...).

(Roston 2011: 1)

No exception is the treatment of the concept in Morreall's book "Comic Relief: A Comprehensive Philosophy of Humor": "The more thoroughly we exist, Kierkegaard says, the more we discover the comic. Tragedy, like comedy, focuses on problems, but while the comic perspective sees a way out, the tragic perspective despairs of a way out" (Morreall 2011: 131). The picture gets even more complicated since now the comic is used not only in the context of comedy, but also as a term that designates humour.

All three quotations above contain reference to laughter; the comic is either used as a synonym to laughter or is a feature that defines a specific type of laughter - the one that necessarily implies social meaning.

It should be noted, however, that the comic as a term is not popular among humour researchers, since another term - humour - successfully functions as a designator for a variety of forms and genres of non-bona fide discourse.

\subsection{Humour}

The two meanings of the word are captured by the Longman Dictionary of Contemporary English (2020):

1. the ability or tendency to think that things are funny, or funny things you say that show you have this ability;

2. the quality in something that makes it funny and makes people laugh.

Similar meanings can be found in other dictionaries of general English. Such descriptions are hardly surprising since they are based on the psychological perception of humour. According to Ruch, "the core of the experience of humor is the perception that something is "funny' (...)" (Ruch 2008: 20). The vagueness of the concept is the reason why humour is often defined by examples which serve as prototypes.

Now let us turn to the description of the concept of humour. Surprisingly, Encyclopedia of Humor Studies does not have a separate entry for the term humour itself. The readers can get information on the etymology of the term, forms of humour and computer-generated humour, but not on the concept of humour per se and its relations with other terms. Interestingly, in other entries, the researchers talk about the overlap between the concepts of humour and absurd, humour and aesthetic experience, humour and incongruity, humour and cognitive challenge, to name but a few (Attardo 2014).

Obviously, humour is one of the most frequently used terms by humour researchers. Discussions of the conceptual boundaries of the fuzzy term are inevitable. When talking about the meaning of the term, Ruch states:

The meaning of humor is best illuminated by fixing its position in the complex net of terms used in the whole field. At present several formal and informal nomenclatures coexist and, unlike in other disciplines, no committee has decided on some common, binding usage of terminology in humor 
research. One historical nomenclature stems from the field of aesthetics (as studied by philosophers and psychologists) where the comic - defined as the faculty able to make one laugh or amuse - is distinguished from other aesthetic qualities, such as beauty, harmony, or the tragic. Humor is simply one element of the comic - as are wit, fun, nonsense, sarcasm, ridicule, satire or irony - and basically denotes a smiling attitude toward life and its imperfections: an understanding of the incongruities of existence. Humor in this narrow sense was seen to be based on a sympathetic heart, not on a superior spirit (like wit), moral sense or even haughtiness/maliciousness (like mock/ridicule, or vitality/high spirits (like fun). In this terminological system, it is not possible to refer to a joke as an example of "aggressive humor" since, humor by definition is benevolent and jokes typically not considered vehicles for humor (...).

The other major terminological system, largely endorsed by current Anglo-American research (and in everyday language), uses humor as the umbrella-term for all phenomena of this field. Thus, humor replaced the comic and was treated as a neutral term; i.e. not restricted to positive meanings. In this context, humor can be "aggressive" and jokes may be considered as humor and form a very frequent subject and domain of study.

(Ruch 2007: 6)

This lengthy quotation explains the terminological shift from the aesthetic approach to the approach that is largely influenced by non-terminological use of the word humour. In a similar vein, Attardo claims that humour is accepted as an umbrella term to cover a wide variety of forms of humorous communication (Attardo 2014).

To sum up, the comic and humour as terms tend to belong to different areas of research, theory of literature and humour studies, respectively. In scholarly writings, they may "keep similar company" (i.e., to explain the comic or humorous effect, researchers may use similar terms, e.g., absurd or incongruity), but the comic as the property of text may imply additional social meaning.

\subsection{Irony}

Most dictionaries describe two meanings of the word irony:

1. A form of humour in which you use words to express the opposite of what the words really mean.

2. A strange, funny, or sad situation in which things happen in the opposite way to what you would expect (MacMillan English Dictionary 2009-2020).

The first meaning gives an idea of a prototypical irony and the second definition presents the socalled situational irony. Interestingly, irony is categorized as a form of humour, so irony is assumed to be funny by default. Just like in the definitions of humour, the word funny is used for description of irony.

In its definition of the word irony, The Collins English Dictionary (2020) is more elaborate:

1. the humorous or mildly sarcastic use of words to imply the opposite of what they normally mean;

2. an instance of this, used to draw attention to some incongruity or irrationality;

3. incongruity between what is expected to be and what actually is, or a situation or result showing such incongruity;

4. dramatic irony;

5. philosophy Socratic irony.

Again, the first meaning describes prototypical irony as the implicit meaning which is opposite to the surface meaning of an utterance. However, irony is categorized as either humorous or sarcastic, which makes things even more confusing, since humour and sarcasm are two different concepts. The second and the third meanings are based on the concept of incongruity of the 
situation. The fourth and the fifth meanings are more specialized: one refers to the domain of theatrical play, another - to the ancient philosopher and his method of dissimulation of ignorance in a competitive dialogue. To sum up, all five meanings shed light on some properties of irony, but the situation reminds of a parable of the blind men and an elephant - it is difficult get a clear understanding of what irony is.

It comes as no surprise that irony, perhaps, is one of the most discussed terms in the field of humour studies. Trying to grasp its essence, researchers use a gamut of research approaches and explanations of how ironic meaning is created and recognised in discourse.

The entry for irony in Encyclopedia of Humor Studies reflects this diversity of approaches by listing a variety of meanings of the term: Socratic irony, romantic irony, postmodern irony, and demonstrates the variety of approaches to irony by mentioning that

"Irony has been considered as a rhetorical figure, an implicature, a speech act, an echoic mention, a
pretense, a reminder, a non-salient interpretation and a tinge (i.e., the two meanings blend into each
other). This list is not exhaustive." (Encyclopedia of Humor Studies 2014: 398)

Indeed, a vast range of approaches to irony and its elusive nature do not allow researchers to agree on a universal definition.

A general definition of irony as "a device of both mind and language for acknowledging the gap between what is expected and what is observed" opens the collection of papers (Irony in Language and Thought 2007: IX). This definition allows the editors of the volume to unite diverse approaches to irony in the papers included in the book.

What conclusions can be made from this brief analysis? Firstly, the opposition of explicit and implicit meanings or a gap between the expected and the reality are sufficient for language speakers to call something 'irony', especially if there is some sort of humorous effect. However, these criteria are not sufficient for a terminological definition, so we are likely to face further debates in academic discussions of irony.

\subsection{Joke / canned joke}

A joke is defined as (1) "something that is said or done to make you laugh, for example a funny story", (2) "a humorous anecdote", or as (3) "something that is said or done for fun; prank" (Collins English Dictionary, 2020). In other words, anything can be classified as a joke as long as it is meant to make someone laugh. Vague definitions like those quoted above give us little information about the essence of jokes, yet, the concept of a joke seems to be intuitively understood by all language speakers. However, when it comes to a terminological definition, difficulties arise (Dynel 2009). "The term joke can be found in two different meanings within humour research. The first is that as a type of text; the second is more generally that of an instance of humor" (Attardo 2014: 417).

In humour studies, jokes in the first sense are defined as "narratives or riddles whose main, though not exclusive, humorous force lies in the punch line, the line at the end of the joke, when there is a sudden and unexpected shift in meaning" (Davies 2011: 3).

A more precise term - canned joke - can be used by researchers to designate a specific genre of humour. "A canned joke is a generally short narrative ending in a punch line, which preexists the setting in which the joke is told (in other words, a canned joke is re-created from a preexisting model the speaker has memorized)" (Attardo 2014: 417). The definition accentuates intentionality and ready-made form of this type of jokes.

The analysis of four key terms of humour research demonstrates their fuzziness. To be able to discuss humorous phenomena, researchers need to illustrate their understanding with 
examples. The situation gets even more complicated when English terms are used by scholars who speak languages other than English as their native, since cognate terms in their languages may be used and understood differently. To illustrate this, in the next section, we will discuss Russian terms, some of which have common origin with their English counterparts and sometimes are used as translation equivalents.

\subsection{Mocking}

The words mock / mocking / mockery denote actions and their results - mocking in general dictionaries is described as making "someone or something look stupid by laughing at them, copying them, or saying something that is not kind" (MacMillan English Dictionary 2020).

As the definition suggests, the acts of mocking are meant to denigrate the target in an unkind way. As a type of behaviour, mocking is not necessarily humorous; rather, it is an aggressive form of interaction.

Humour researchers use the words mock, mocking, mockery to describe a specific type of humorous discourse. The Encyclopedia of Humor does not contain an entry for mock/mockery. However, it is interesting to know what "company they keep" (Firth 1957) across the text of the volume. The most frequent collocates are the words ridicule, satire, irony, and sarcasm. Mockery always implies social distancing, as it is used to criticize or denigrate people, stereotypes, social norms and values. On three occasions, however, the act of mocking is described as either gentle or aggressive, which means that the concept of mocking can potentially describe any type of action aimed at laughing at someone.

\subsection{Banter}

The word banter is infrequent in humour research. However, we decided to include it in our research since Russian-English dictionaries treat it as a translation equivalent for the words подиучивание and подтрунивание which will be discussed in the next section.

Banter is "a friendly conversation in which people make a lot of jokes with, and amusing remarks about, each other" (Longman Dictionary of Contemporary English Online 2020).

According to the Encyclopedia of Humor, banter is a conversational genre: "The rapid exchange of humorous lines oriented toward a common theme, though aimed primarily at mutual entertainment rather than topical talk, typifies what we generally call banter. It may consist primarily of sarcastic comments, wordplay, or both in the usual sense of punning, metaphor, and so on" (Attardo 2014: 176).

Banter is a competitive type of discourse which requires demonstration of light humour and wit. In the Encyclopedia of Humor, the nearest collocates of banter are laughter, jokes, teasing, and punning. This demonstrates that banter is a harmless type of humour aimed at entertaining and not at expressing social norms and values. Special attention should be paid to competitiveness as its specific feature - as it will be demonstrated later, the Russian words подиучивание and подтрунивание nominate unidirectional action toward the target and do not imply any contest or rapid exchange of humorous utterances.

\section{Russian humour terms}

The analysis of Russian humour terms followed the same steps: two types of dictionaries and professional texts were used as sources which demonstrate naïve and scholarly understanding of the words. Since the word joke in Russian can be translated as either шутка or анекдот, seven 
terms were chosen for the analysis: комическое (комизм), юмор, ирония, иутка, анекдот, насмешка, and подиучивание.

\section{1. Комическое, комизм - the comic, the comical effect / the comic element}

We will begin our analysis of Russian humour terminology with the description of the umbrella term комическое (the сотіс) which is widely used by Russian scholars to refer to a variety of forms and genres of the humorous mode of the non-bona fide $e^{1}$ discourse.

The tradition to use this term to denote almost any display of non-bona fide behaviour, both verbal and non-verbal, comes from aesthetics. The nominalized adjective комическое stems from the adjective комический (сотіс). Russian dictionaries define the adjective комический as either something that refers to a comedy or as something funny. None of the explanatory dictionaries has an entry for комическое (the comic) - as a nominalized adjective - apparently, the term is too specific to be included in the dictionaries of general language.

Scholarly use of these terms can be illustrated by a seminal work of Vladimir Propp (Propp 1976, English translation 2009). Remarkably, in his analysis of classical Russian literature, Propp does not attempt to give a precise definition of "the comic". Instead, he tells his readers what the "comic" is not. Here are just two examples from the English translation of Propp's book:

That the comic is the opposite of the sublime and the tragic is an assumption taken on trust but doubts about the adequacy of this sort of opposition were already expressed in nineteenth-century positivistic German aesthetics. For example, Volkelt wrote: "In the domain of aesthetics, the comic is identified from a point of view completely different from the tragic"; "The comic is not an opposite category of the tragic, and it cannot be placed on the same level as it (...). If anything is opposed to the comic, it is the non-comic or the serious (...)". He states the same thing about the sublime. This notion, expressed also by others, is undeniably correct and fruitful. The comic should be studies primarily in itself (...).

(Propp 2009: 5)

"The comical" and "humour", Hartmann $(1958,604)$ writes, "are certainly closely interconnected, but they by no means coincide, and they are nominally not parallel either". Humour is a certain state of mind that occurs in our relations with people when we happen to notice their positive inner nature behind their minor external flaws.

(Propp 2009: 120)

Propp's aesthetical approach to what in modern English-dominated terminological tradition would be described as either humour, irony or sarcasm demonstrates that, for him, just as for many other Russian scholars, комическое is used as a general term which comprises a variety of forms and types of humour. The same applies to the use of the term to denote an aesthetical category in philosophy (see, for instance, Borev (1970)). The Dictionary of Philosophy defines комическое as follows:

Комическое - категория эстетики, выражающая в форме осмеяния исторически обусловленное (полное или частичное) несоответствие данного социального явления, деятельности и поведения людей, их нравов и обычаев объективному ходу вещей и эстетическому идеалу прогрессивных общественных сил. К. по своему происхождению,

\footnotetext{
${ }^{1}$ Humour is an example of the so-called non-bona fide mode of discourse which was described by Viktor Raskin and Salvatore Attardo as the type of communication which intentionally violates the maxims of Grice's cooperative principle, especially the maxim of quality, and "(...) is governed by different principles that do not include the commitment to the (literal) truth of the utterances" (Raskin \& Attardo 1994).
} 
сущности и эстетической функции носит социальный характер. Его истоки коренятся в объективных противоречиях общественной жизни. К. может проявляться по-разному: в несоответствии нового и старого, содержания и формы, цели и средств, действия и обстоятельств, реальной сущности человека и его мнения о себе. Видом К. является, напр., попытка безобразного, исторически обреченного, бесчеловечного лицемерно изображать себя прекрасным, передовым и гуманным. В этом случае К. вызывает гневный смех и сатирическое, отрицательное отношение. Маркс считал смех сильным орудием революционной критики в борьбе против отживающего. К. имеет различные формы: сатира, юмор и т. д.

(Frolov, Ado 1986: 206)

The comic - the category of aesthetics which expresses the historically contingent (either full or partial) incongruity between a specific social phenomenon, activity or people's behavior, their dispositions and traditions and objective course of life and aesthetic ideal of progressive public opinion. By its genesis, nature and aesthetic function the comic is a social phenomenon. It stems from objective inconsistency of social life. The comic can have its roots in the incongruity between the new and the old, the content and the form, the aim and the means, the action and the circumstances, the real essence of a person and his/her self-esteem. For instance, a type of the comic is an attempt to hypocritically present something ugly, historically doomed and inhumane as something beautiful, progressive and humanistic. In this case, the comic causes angry laughter and negative satiric evaluation. Karl Marx considered laughter to be a tool for revolutionary critique in the combat against the obsolete. The comic can take different forms, e.g., satire, humour etc. ${ }^{2}$

The definition accentuates the social nature of the category and shows that the term can refer to a variety of possible forms of expression.

Another good example of using the nominalized adjective комическое as the umbrella term is the definition of the concept from the Encyclopedic dictionary of Aesthetics:

Комическое - эстетическая категория, обозначающая все то, что является противоположностью серьезного и трагического в жизни и искусстве и что порождает у человека характерную психологическую реакцию в виде улыбки, смеха, хохота. Основанием комического является обнаружившееся противоречие между сутью чего-либо и ее проявлениями, отклоняющимися от этой сути.

(Estetika. Entsiklopedicheskij slovar' 2000-2020)

The comic - an aesthetic category denoting anything that is in contrast with serious and tragic in life and art and what typically causes a psychological reaction of a smile, laughter or roar. The contradiction between the essence of something and its manifestations which deviate from this essence forms the basis for the comic.

As an aesthetic category, the comic embraces all forms and genres of the non-bona fide mode of discourse. It is also important that, for many Russian scholars, the comic conveys social implications: when used in literary texts or by mass media, instances of the comic entertain the readers and, at the same time, create additional social meanings - some sort of social corrective.

Incidentally, in the majority of texts of the second half of the $20^{\text {th }}$ century, the comic is used interchangeably with the term humour:

C восприятием комического дело обстоит совсем иначе. В начале XX в. Луиджи Пиранделло в книге о юморе, ныне почти забытой, указал на то, что основной механизм юмора - особая рефлексия, рождающая в субъекте «чувство противоположного»

(Kozintsev 2007: 32)

\footnotetext{
${ }^{2}$ All Russian texts were translated by Ksenia Shilikhina.
} 
The perception of the comic is very different. In the early $20^{\text {th }}$ century, in his book on humour, almost forgotten by now, Luigi Pirandello pointed out that the main mechanism of humour is a specific reflection which triggers "the feeling of the opposite" in a person.

The term the comic comes in handy, since it embraces a variety of forms of humorous discourse. It comes as no surprise that the term appears in the titles of research papers (e.g. The Comic Text. The Problem of Identifying Speech and Situational Comic in the Text (Kapatsinskaya 2007) or Pragmatic and Linguistic Bases for the Comic (Golosova 2016)). The Russian Science Citation Index contains more than 39000 of papers in which комическое is used either in the title or as a key word (just to compare - only 2567 publications contain the noun юмор (humour) and 335 papers contain the adjective юмористический (humorous) in their titles or as key words) (The Russian Science Citation Index, 2000). However, when the readers delve into the content of the papers, they are very likely to find analyses of various instances of humour in different genres and spheres of discourse.

\section{2. Юмор - humour}

The Russian word юмор was borrowed from English. According to the data of the Russian National Corpus, the word came into active use in the middle of $19^{\text {th }}$ century. Figure 1 shows the relative frequency of the word юмор per 1 million words from 1800 to 2014.

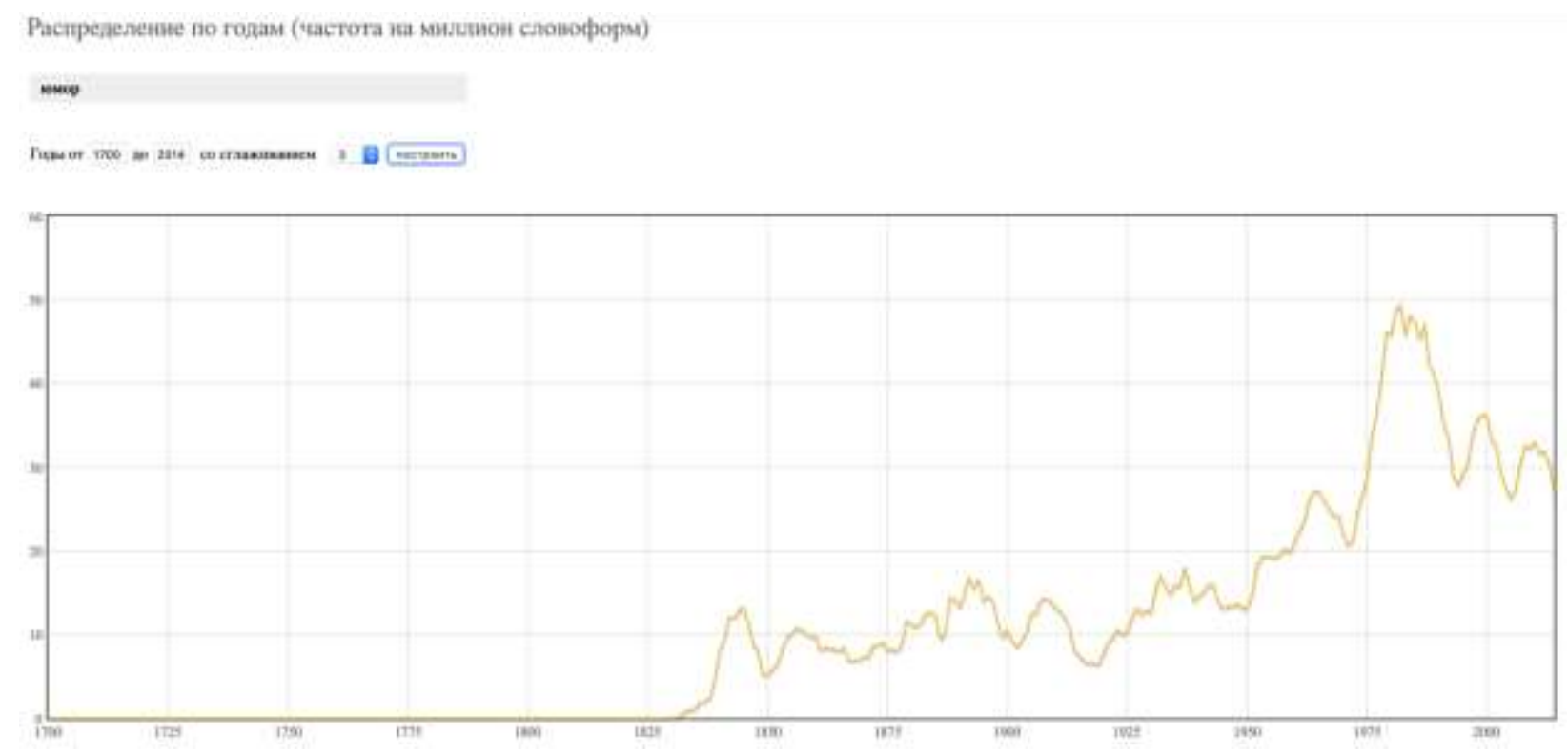

Figure 1. The relative frequency of the word юмор per 1 million words from 1700 to 2014

According to the graph, the word was not frequently used until the middle of the $20^{\text {th }}$ century. The peak values were registered in 1990-es, when humor in all possible forms helped people go through the painful social transition from the Communist era and poverty of 1990 -s to a more stable life in 2000-s.

The Large Explanatory Dictionary of the Russian language describes two meanings of the word юмор and gives an English equivalent without any reference to its Latin roots:

ЮМОР, -а; м. (англ. humour)

1. Умение подметить смешную сторону кого-, чего-л. и представить, показать её в незлобивонасмешливом виде; проникнутое шутливым, добродушно-насмешливым настроением отношение к кому-, чему-л. Чувство юмора. Рассказывать что-л. с юмором. Понимать ю. 
2. Художественный приём в искусстве: изображение чего-л. в смешном, комическом виде. Цирковой ю. Ю. и сатира.

(Kuznetsov, 1998)

HUMOUR (from the English 'humour')

1. The ability to notice funny features of someone or something and represent or show them in a kind and funny way; a funny and light-hearted mood or attitude toward someone or something. A sense of humour. To talk in a humorous manner. To understand humour.

2. A stylistic device in art: a portrayal of something in a funny, comic way. Circus humour. Humour and satire.

It is easy to notice that, unlike in English dictionaries, humour is described not only as a psychological reaction, but as a way of talking about or demonstrating something. Reference to English gives a false impression that these words can be used as translation equivalents. However, as it will be demonstrated later, English and Russian words humоur and юмор share their meanings only partially and, in many cases, humour and юмор are false friends.

Another way of presenting the meaning of юмор is chosen in Efremova's New Explanatory Dictionary of the Russian Language (Efremova 2000). Humour as a type of behaviour is described separately from theoretical understanding of humour as a stylistic tool or a range of literary works:

I

1. Добродушный смех, незлобивая насмешка.

2. Отношение к чему-либо, проникнутое таким настроением.

Умение представить события, недостатки, слабости в комическом виде.

II

1. Художественный приём в литературе и искусстве, основанный на изображении чеголибо в комическом, смешном виде.

2. Совокупность художественных произведений, проникнутых таким отношением к действительности.

(Efremova 2000)

I

1. Kind-hearted laughter, gentle mockery.

2. The attitude toward something, based on such mood.

II

1. A stylistic tool used in literature and art, based on a humorous, funny representation of something.

2. A collection of art works based on this kind of attitude towards reality.

It is interesting to compare definitions presented in the two dictionaries. Both dictionaries describe humour as a specific attitude and expression of light-hearted, gentle mockery. The definition in Efremova's dictionary uses the word laughter to categorize humour. Neither definition contains any reference to the comic.

The Large Encyclopedic Dictionary gives a more elaborate description of the concept. Humour is categorized as a specific type of the comic; to illustrate instances of humour, references to writers are used:

ЮМОР (англ. humour) - особый вид комического, сочетающий насмешку и сочувствие, внешне комичную трактовку и внутреннюю причастность к тому, что представляется смешным. В отличие от "разрушительного смеха", сатиры и "смеха превосходства" (в т. ч. иронии), в юморе под маской смешного таится серьезное отношение к предмету смеха и даже оправдание "чудака", что обеспечивает юмору более целостное отображение существа 
явления. Личностная (субъективная) и "двуликая" природа юмора объясняет его становление в эпоху Позднего Возрождения и дальнейшее освоение и осмысление в эпоху романтизма (Жан Поль). Главные представители в литературе: Сервантес, Л. Стерн, Ч. Диккенс, Н. В. Гоголь, М. Твен

(Prokhorov 1997).

HUMOUR (Engl. Humour) - a specific type of the comic which combines mockery and sympathy, explicit comic rendering and inner belonging to whatever seems to be funny. Unlike "destructive laughter", satire or "superiority laughter" (including irony), humour under the mask of something funny hides a serious treatment of the subject and even justification of "a nerd", which allows humour to give a more holistic representation of the essence of the phenomenon. Personal (subjective) and "double-faced" nature of humour explains its appearance in the Late Renaissance and its further conceptualization during the Romanticism (Jean Paul). The major representatives in literature: Cervantes, L. Stern, Ch. Dickens, N.V. Gogol, M. Twain.

The description of the concept is aimed at demonstrating social functions of humour as an aesthetic phenomenon. There are no references to light-hearted attitude or mood. According to the definition, humour is a rather serious matter with deep social implications.

Interestingly, the Encyclopedic dictionary of Aesthetics does not have an entry for юмор. Apparently, the term комическое presented there meets the need to describe humorous side of life in aesthetics.

In their writings, researchers use the term юмор as a synonym for the comic, laughter or even vivacity (see, for instance, Verzhinskaya (2011)). Often, humour is used in collocations humour and satire, humour and irony, humour and sarcasm, i.e., humour is treated as a type of the comic. For instance, humour is defined as the type of the comic in Duskaeva's reference book "Medialinguistics in terms and concepts" (Duskaeva 2018a). The researcher finds this taxonomic relation feasible for the description of a specific sphere of discourse within the praxiological approach (Duskaeva 2018b).

\section{3. Ирония - irony}

According to the Russian National Corpus, the word ирония came into active use in the early $19^{\text {th }}$ century and since then its relative frequency ranges from 12 to 25 occurrences per 1 million words (see Figure 2).
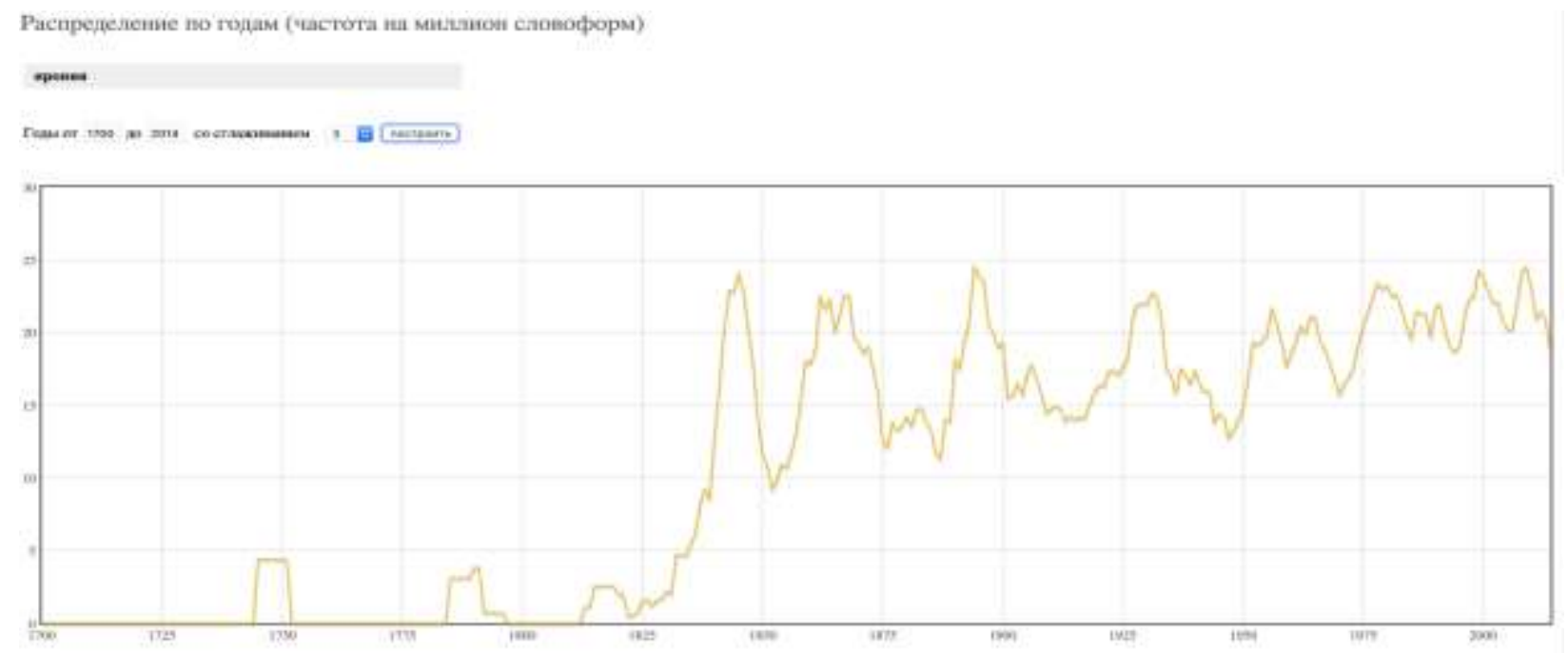

Figure 2. The relative frequency of the word иронияper 1 million words from 1700 to 2014 
The dictionary entry in the Russian Explanatory Dictionary (Efremova 2000) contains two meanings of the word: the first describes prototypical irony; the second presents its terminological use in the theory and history of literature:

1. Тонкая насмешка, прикрытая серьезной формой выражения или внешне положительной оценкой.

2. Стилистический приём контраста видимого и скрытого смысла высказывания, создающий эффект насмешки (в литературоведении).

3. A subtle mock covered by a serious form of expression or positive evaluation.

4. A stylistic device in which the explicit and implicit meanings of the utterance are contrasted, thus creating the effect of mockery (in theory and history of literature).

The Large Encyclopedic Dictionary contains a more elaborate description of irony:

ИРОНИЯ (от греч. eironeia - притворство)

1. отрицание или осмеяние, притворно облекаемые в форму согласия или одобрения

2. Стилистическая фигура: выражение насмешки или лукавства посредством иносказания, когда слово или высказывание обретает в контексте речи смысл, противоположный буквальному значению или отрицающий его.

3. Вид комического, когда смешное скрывается под маской серьезного (в противоположность юмору) и таит в себе чувство превосходства или скептицизма.

(Prokhorov 1997)

IRONY (from the Greek ironeia - pretense)

1. Negation or mockery cast into the form of a mock agreement or approval.

2. A stylistic figure of speech: the expression of mockery or deceit by means of indirectness, when, in the context, a word or an utterance acquires a new sense which is opposite to its literal meaning or which negates it.

3. A type of the comic, when the funny is hidden behind a serious mask (opposite to humour) and implies the feeling of superiority or skepticism.

Both explanatory and encyclopedic dictionaries focus on the discrepancy between the said and the meant. The encyclopedic definition categorizes irony as a type of the comic.

There is a strong tradition among Russian researchers to treat irony as a type of the comic (Pokhodnya 1989; Ermakova 2005). As such, irony is often treated not as something people do in discourse, but as an aesthetic phenomenon:

Понимая всю приблизительность и ограниченность кратких дефиниций, автор определяет иронию как эстетическую и нравственную категорию, служащую для обозначения эмоционального эмоционально-ценностного отношения, которое будучи видом комического, характеризуется трехплановой структурой при относительной равноценности этих планов, амбивалентностью, возможностью двунаправленности и особым характером выражения.

(Pivoev 2017: 102)

Understanding all the roughness and limitations of short definitions, the author defines irony as an aesthetic and moral category that serves to denote an emotional-value relationship, which, being a kind of comic, is characterized by a three-plan structure with relative equivalence of these planes, ambivalence, the possibility of bi-directionality, and a special character of expression.

The tradition to treat irony, as well as humour, as a type of the comic and as an aesthetic phenomenon is characteristic not only of the theory and history of literature, but also of the linguistic and discursive analyses. 


\section{4. Шутка (a joke)}

The word иутка (a joke) is used since early $18^{\text {th }}$ century. The graph demonstrates the increase of frequency of its use in the middle of $19^{\text {th }}$ century and stable use of the word since 1950s (see Figure 3).

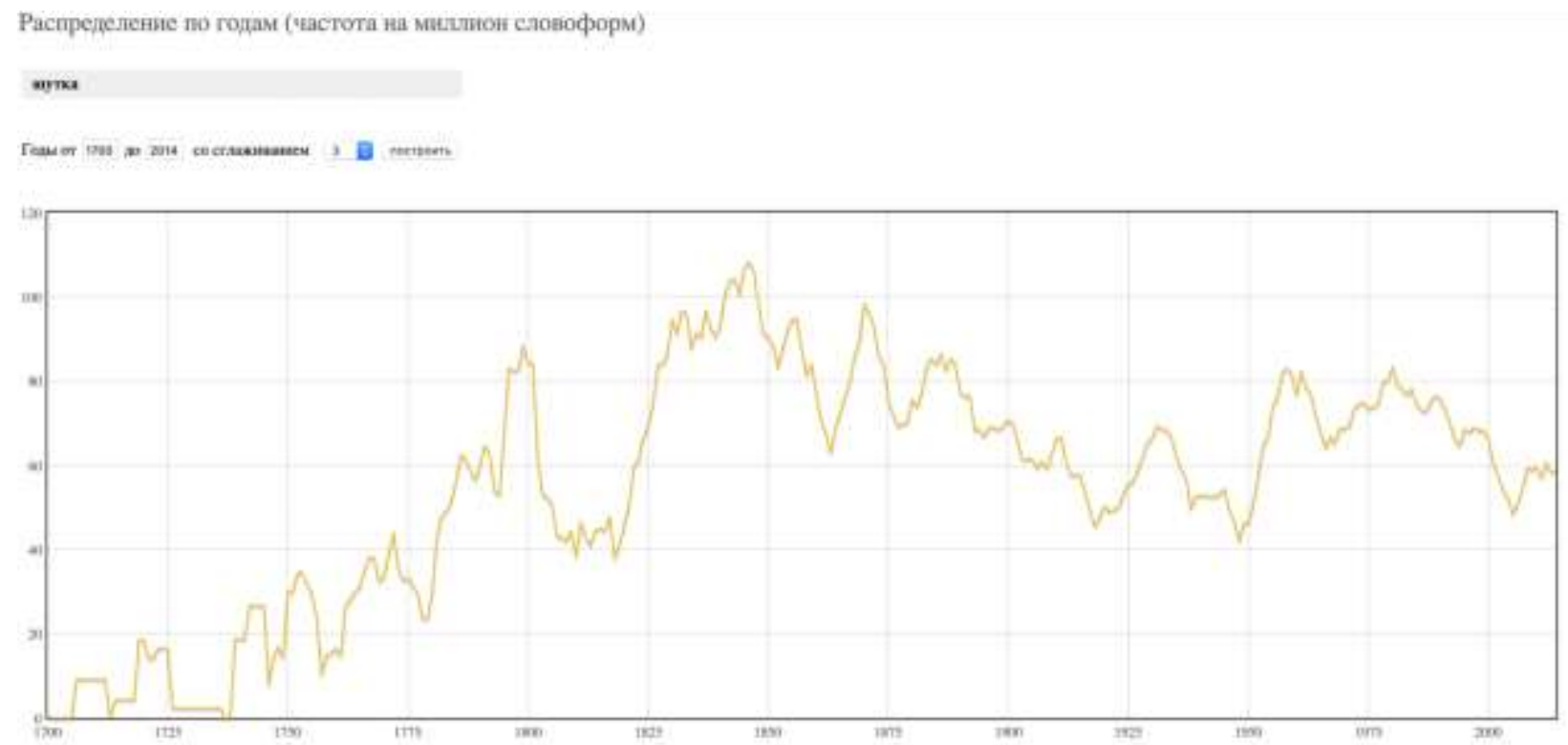

Figure 3. The relative frequency of the word шутка per 1 million words from 1700 to 2014

The dictionary definitions of the word шутка are rather brief and vague:

1. То, что говорят или делают с целью вызвать смех, веселье; забавная выходка, шалость.

2. То, что говорят или делают не всерьез, к чему нельзя относиться серьезно.

(Efremova 2000)

1. What is said or done with the purpose to cause laughter or merriment; a funny trick, a prank.

2. What is said or done non-seriously, something that cannot be taken seriously.

Both meanings highlight the non-bona fide nature of jokes and their intentionality. Interestingly, apart from laughter and non-seriousness, no other humour words are used in the definitions. No formal properties of jokes (e.g., text structure or word play) are mentioned either.

Dictionary of Philosophy describes the concept in a more elaborate manner, categorizing it as a comic phenomenon and comparing it to humour:

ШУТКА - комический контраст в жизненной ситуации, вызывающий смех, отмечающий одновременно и различие, и связи. Обозначает также способность подмечать этот контраст и наглядно его изображать. При этом шутка большей частью скользит по поверхности и не охватывает ситуацию в целом, как это свойственно юмору.

(Filosofskij slovar' 2010)

JOKE - a comic contrast in a life situation that causes laughter and marks differences and connections simultaneously. Also denotes the ability to see this contrast and represent it. At the same time, unlike humour, a joke is a superficial phenomenon that does not capture the situation on the whole. 
In academic writings, the term $ш у т к а$ is used to designate any instance of word play, or a funny remark or an action.

\section{5. Анекдот (a canned joke)}

The data from the National Russian Corpus demonstrate that the word анекдот came into usage in 1770-s (see Figure 4). It was borrowed from French and, until 1920-1930-s, it was used to describe an entertaining story about something interesting that happened to a well-known person or a folklore character. The meaning of the Russian borrowing was very close to the French and English anecdote - a short account of an entertaining or interesting incident. However, starting from 1920-1930-s, it became a name for a specific type of joke - namely, canned joke. It also gave rise to the word anekdotchik (anecdotalist) - a person whose habit is to tell canned jokes in public (Shmeleva, Shmelev 2002). The old meaning was almost forgotten - now it can be found only in dictionaries. For younger generations of speakers of Russian, анекдот is the name of a very popular folklore genre of humour.

Not only the meaning, but also the frequency of the word was subject to change with time. The graph (Figure 4) shows how popular the word became at the very end of the $18^{\text {th }}$ century. Low frequency of the word around 1930-1950-s reminds us how dangerous it was to tell jokes under Stalin (for more historical details see Arkhipova \& Melnichenko (2001) and Waterlow (2018)). The rise of frequency that followed is a sign of what C. Davies termed as "unique popularity" of the genre. The popularity itself can be explained by the specific social reality reflected in jokes (Davies 2007).
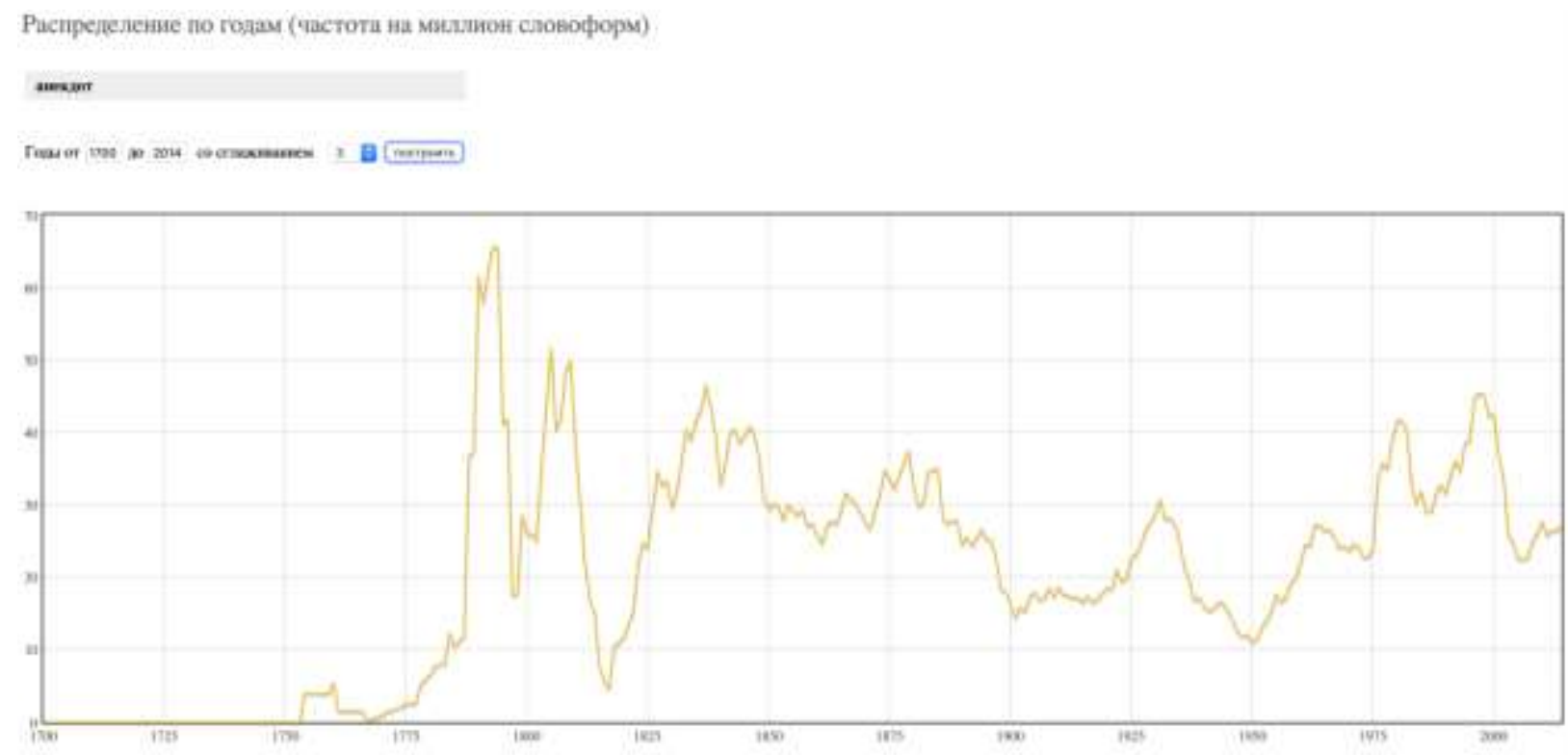

Figure 4. The relative frequency of the word анекдот per 1 million words from 1700 to 2014

Modern dictionaries define анекдот as follows:

1. Короткий рассказ о каком-либо вымышленном событии, забавном случае. Само это событие, сам этот случай.

2. Устный короткий рассказ с неожиданным остроумным концом. 
1. A short story about a fictional event or funny occasion. The event or the occasion itself.

2. A short oral story with an unexpected witty final.

The lexicographer does not use the word joke in the definition and describes the word анекдот as a type of text. In the same vein, the encyclopedic description of the concept does not categorize анекдот as a type of joke:

Анекдот - (греч. anekdotos - неопубликованный рассказ), комический жанр; лаконичный рассказ с занимательным сюжетом, представляющим жизненную ситуацию, попав в которую его герой проявляет находчивость или демонстрирует остроумие.

(Nikolaev, Stroganov 2006)

Canned joke (from Greek anekdotos - an unpublished story) - a comic genre; a short story with an amusing plot describing a situation in which a character demonstrates quick-wittedness or shows wit.

The definition starts with a reference to the comic - again, it is used as an umbrella term for categorization of yet another term.

In their book "Russian canned jokes", Shmeleva and Shmelev define анекдот as a short oral story about a fictional situation with an unexpected witty final. The characters of the story are well known to all speakers of Russian (Shmeleva \& Shmelev 2002: 20). This allows canned jokes to function in various spheres of discourse (Shilikhina 2013; Vasileva 2017). This definition is the closest to the English concept of a canned joke. However, the word юмор (humour) is not used in any of the definitions. The only reference to the humorous nature of this genre is the mention of a witty final.

\section{6. Насмешка (mockery)}

The Russian word насмешка is derived from the word cмex (laughter). According to dictionaries, насмешка means "Обидная шутка, издевка, выражение иронического отношения" (Ushakov 2006) - an offensive joke, mickey-taking or expression of ironic attitude. This means that, for speakers of Russian, the word насмешка denotes a verbal action within the non-bona fide mode, with the primary intention to offend (but not to present as ridiculous!) someone. The word itself is used by lexicographers in the definitions of other terms, e.g., irony and sarcasm.

In research, the word is often used by the theorists of literature in two ways: it can be used as a synonym for parody or laughter at someone or as a term that refers to the ironic effect produced by the text. The first quotation below demonstrates close connection between cmex (laughter) and насмешка (mockery):

Однако ввиду того, что смех непроизволен, стихиен и бессознателен, люди... толкуют его вкривь и вкось и связывают именно с чувствами и оценками, о чем свидетельствует, в частности, слово «насмешка».

(Kozintsev 2007: 53)

However, because laughter is unintentional, spontaneous and unconscious, people (...) explain it in a haphazard manner and connect it with feelings and evaluation, and this is marked by the existence of the word "mockery".

Насмешка as the ironic evaluation often is a sign of social critique:

Ирония поэтому может использоваться как риторический, литературный прием (тонкая насмешка, выраженная в скрытой форме), как похвала «с двойным дном», как 
двусмысленность, в которой за положительной внешней оценкой стоит отрицание и насмешка,

(Riumina 2010: 117)

For this reason, irony can be used as a rhetoric or literary device (an implicit expression of a subtle mockery), as a praise with a "false bottom", as ambiguity in which, behind the praise, there is negation and mockery.

To sum up, Russian насмешка is predominantly a verbal action or a type of laughter which can be intended as an insult or imply hidden ironic attitude. Насмешка is used by researchers as a term to designate author's intention to express critical attitude.

\section{7. Подшучивание (gentle mocking / badinage/ banter)}

The word подиучивание (banter / badinage) means the act of laughing at someone with the aim of making someone look stupid (Efremova 2000). Подшучивание means that someone becomes the target of a witty comment or a joke, and often the person who has become the target of the joke is physically present, so he/she can reply to a joke.

In research writings, the word is sometimes used to denote instances of mild irony which can also involve word play. Подиучивание is a milder form of making fun of someone, usually contrasted with irony, satire or sarcasm as more spiteful types of humour.

\section{Comparative analysis of the two terminologies}

Even this rather short and sketchy description of just six English and seven Russian terms demonstrates differences in their "naïve" and scholarly understanding.

\subsection{The comic vs. комическое}

The English noun the comic is not used in humour research as widely as the Russian term комическое - its usage is limited to the field of the theory and history of literature. While, in Russian, комическое is a hypernym for the whole system of terms, in the English language, humour functions as an umbrella term. For the speakers of Russian, especially in scholarly analysis of any genres and forms of humour, the term комическое also implies social meaning created by the non-bona fide use of language. Since the comic as a term is used in English to denote something that refers to a comedy as a literary form, it cannot be considered a translation equivalent for the Russian комическое.

Perhaps, for this reason, Russian-English dictionaries tend not to give any translation equivalents for the nominalized adjective комическое. As for the noun комизм, lexicographers suggest comicality and the comic element as translation equivalents.

\subsection{Humour vs. юмор}

The same is true about huтоur and юмор: in many contexts, these terms can be treated as false friends, since the English word serves as an umbrella term for many forms of non-serious communication, while the Russian юмор designates a specific light-hearted form of discourse aimed at amusement and laughter.

Though in both languages humour and юмор imply funniness, for the speakers of English, humour is a way of perception of a situation, while, for the Russians, юмор is a kind of activity, a way of presenting the state of affairs. 


\subsection{Irony vs. ирония}

In both Russian and English, the terms denote implicit meaning which is the opposite of what is said. However, for the speakers of English, irony is a type of humour, while it is categorized as a type of the comic in Russian.

Irony is an important cultural phenomenon. That is why several attempts have been made by Russian scholars and interpreters to explain what English irony is by comparing it to the Russian term ирония.

One of the top Russian interpreters, Palazhchenko notes that the English irony has a slightly different meaning from the Russian word ирония: the former implies incongruity (this brings us back to the definition of irony in Collins English Dictionary) and paradox. These implications are reflected by the dictionaries of synonyms. Consequently, in many contexts, English irony should be translated as парадокс (а paradox), but not as ирония (irony) (Palazhchenko 2017). It should be noted, however, that the examples of English contexts and their Russian translations given in Palazhchenko's dictionary refer to the state of affairs in the world, i.e. to situational irony.

Gornostaeva compares Russian and English concepts irony and ирония and concludes that they cannot be considered equivalent: while English dictionaries often describe irony as something funny or humorous, for the speakers of Russian, ирония is the tool for mocking and ridicule (Gornostaeva 2013). This conclusion is in line with the existing tradition to highlight social value of irony.

\section{4. (Canned) joke vs. шутка and анекдот}

In both languages, a joke and иутка are described as verbal or non-verbal actions aimed at making people laugh. The Russian concept is categorized as a type of the comic and, from the aesthetic and philosophical point of view, it is contrasted with humour: while the latter is aimed at implicit expression of social values, the former is a more superficial phenomenon.

In Russian, the word анекдот is used to designate the genre of canned jokes. While the English cognate word anecdote still denotes a witty story about a well-known person, the Russian word анекдот changed its meaning over time and, in modern usage, it designates a folklore genre of canned jokes.

\subsection{Mocking / banter (badinage) vs. насмешка / подтрунивание}

Mocking and насмешка both reflect the idea of aggressive form of ridicule. However, the English mocking, in its general sense, does not have to be humorous, while the Russian word implies some sort of funniness. Also, Russian насмешка is defined as a type of verbal action, while mocking in English can take other forms, for instance, copying. As for its terminological use, the Russian word can be used as a synonym to irony or laughter, so the choice of a translation equivalent largely depends on the context.

Banter is incorrectly treated by many Russian-English dictionaries as the translation equivalent for the Russian подшучивание. In this case, gentle mocking or ironic badinage are more appropriate ways of translation since they reflect the idea of kind intentions and lack of aggression on the part of the speaker.

\section{Conclusion}

In both Russian and English languages, domain-specific terms of humour came naturally from commonly used words - various forms of humour, irony and sarcasm are embedded in our social practices and people talk about them using the same words that humour scholars use in their 
research. The vagueness of terms and the abundance of approaches to humorous phenomena (aesthetic, literary, linguistic, cognitive, psychological, anthropological, etc.) explain why scholars cannot agree on precise definitions.

Differences in the two terminologies lead to considerable difficulties in translation or adequate explanation of humorous phenomena. While the aesthetic term the comic is still the umbrella term covering all forms and genres of non-bona fide mode of discourse for the Russian scholars, for those who use the English terminology, the term humour functions in a similar way. So, whenever Russian комическое is translated humour by the English, it creates terminological confusion and misunderstanding for Russian scholars, since the Russian word юмор has a much narrower meaning. The same applies to the translation of комическое as the comic: for the English-speaking readers, it looks somewhat alien or old-fashioned.

The problem of standardisation of terminology is still to be solved. However, systematic comparisons of national terminologies can help in resolving the issue.

\section{Acknowledgements}

The study was carried out with the financial support of the RSF: grant 19-18-00530 Humour as a communicative resource in the digital news environment.

\section{References}

Arkhipova, A. S. \& Melnichenko, M. A. (2011). Anekdoty o Staline. Teksty, kommentarii, issledovanija [Canned Jokes about Stalin. Texts, comments, research]. Moscow: OGI.

Attardo S. (ed.) (2014). Encyclopedia of Humor Studies. Thousand Oaks, California: SAGE Publications.

Berger, P. L. (2014). Redeeming Laughter: The Comic Dimension of Human Experience. Berlin/Boston: Walter de Gruyter.

Borev, Y. (1970). Komicheskoe [The Comic]. Moscow: Iskusstvo.

Collins English Dictionary (2020). Retrieved $27 \quad$ March 2020 from https://www.collinsdictionary.com/browse/english/

Colston H. L. \& Gibbs R. W. (eds.) (2007). Irony in Language and Thought. New York: Lawrence Erlbaum Associates.

Davies, C. (2007). 'Humour and Protest: Jokes under Communism'. International Review of Social History 52, pp. 291-305.

Davies, C. (2011). Jokes and Targets. Bloomington: Indiana University Press.

Drame, A. (2015). 'The social and organizational context of terminology work', in Kockaert, H. J. \& Steurs, F. (eds.), Handbook of terminology, Amsterdam / Philadelphia: John Benjamins, pp. 505-520.

Duskaeva, L. R. (2018a). Media linguistics in terms and concepts: reference book. Moscow: Flinta.

Duskaeva, L. R. (2018b). 'The dynamic and static aspects of speech organization in business media texts'. Studies About Languages 2, pp. 65-76.

Dynel, M. (2009). 'Beyond a Joke: Types of Conversational Humour'. Language and Linguistic Compass 3 (5), pp. 1284-1299.

Efremova T. F. (2000). Novyj slovar' russkogo jazyka. Tolkovo-slovoobrazovatelnyj [The New Russian Explanatory and Word-Formative Dictionary]. Moscow: Russkij jazyk.

Ermakova, Olga P. (2005). Ironija i ee rol'v zhizni jazyka [Irony and its role in the life of language]. Kaluga: KGPU Press. 
Estetika. Entsiklopedicheskij slovar [Aesthetics. Encyclopedic dictionary] (2000-2020). Retrieved 27 March 2020 from https://aesthetics_ru.academic.ru.

Filosofskij slovar [Dictionary of Philosophy] (2010). Retrieved 5 April 2020 from https://mydict.ru/dic/filosofskiy-slovar/.

Firth, J. (1968 [1957]). 'A synopsis of linguistic theory 1930-55', in Palmer, F. R. (ed.), Selected Papers of J. R. Firth 1952-59, London: Longman, pp. 168-205.

Frolov, I. T. \& Ado A.V. (eds.) (1986). Filosofskij slovar [Dictionary of Philosophy]. Moscow: Izdatelstvo politicheskoi literatury.

Golosova, N. V. (2016). 'Pragmalingvisticheskie osnovanija komicheskogo' [Pragmatic and Linguistic Bases for the Comic]. Philological Sciences. Issues of Theory and Practice 6 (60), pp. 81-83.

Gornostaeva, A. (2013). 'Ironia v anglijskoj i russkoj kommunikativnykh kul'turakh' [Irony in the English and Russian Communicative Cultures]. Dissertation Abstract. Moscow: Russian University of People's Friendship.

Hacken, P. (2015). 'Terms and specialized vocabulary: Taming the prototypes', in Kockaert, H. J. \& Steurs F. (eds.), Handbook of terminology, Amsterdam: John Benjamins Publishing Company, pp. 3-13.

Hartmann, R. R. K. \& James G. (1998). Dictionary of Lexicography. London/New York: Psychology Press.

Hempelmann, C. F. \& Gironzetti, E. (2015). 'An interlingual study of the lexico-semantic field LAUGH in Ken Kesey's One Flew over the Cuckoo's Nest'. Journal of Literary Semantics 44 (2), pp. 141-167.

Hempelmann, Ch. F. (2017). 'Key Terms in the Field of Humor', in Attardo S. (ed.), The Language Handbook of Language and Humor, New York/London: Routledge, pp. 34-48.

Kapatsinskaya, V. M. (2007). 'Komicheskij tekst. Problema vydelenija rechvogo i situativnogo v komicheskom tekste' [The Comic Text. The Problem of Identifying Speech and Situational Comic in the Text]. Proceedings of N.I. Lobachevsky Nizhny Novgorod University 3, pp. 224-228.

Kozintsev A. G. (2007). Chelovek i smekh [Human and Laughter]. Saint-Petersburg: Aleteija.

Kuznetsov S. A. (ed.) (1998). Bolshoj tolkovyj slovar' russkogo jazyka [The Large Explanatory Dictionary of the Russian Language]. Saint-Petersburg: Norint.

L'Homme M.-C. (2020). Lexical Semantics for Terminology. An Introduction. Amsterdam/ Philadelphia: John Benjamins Publishing Company.

L'Homme M.-C. \& Marshman E. (2006). 'Terminological Relationships and Corpus-based Methods for Discovering Them: An Assessment for Terminographers', in Bowker, L. (ed.) Lexicography, Terminology and Translation: Text-based Studies in Honour of Ingrid Meyer, Ottawa: University of Ottawa Press, pp. 67-80.

Longman Dictionary of Contemporary English Online (2020). Retrieved 27 March 2020 from https://www.ldoceonline.com.

MacMillan English Dictionary (2009-2020). Retrieved 27 March 2020 from https://www.macmillandictionary.com.

Morreall, J. (2011). Comic Relief: A Comprehensive Philosophy of Humor. Oxford: WileyBlackwell.

Nikolaev P. A. \& Stroganov M.V. (eds.) (2006). Literatura i jazyk. Sovremennaja illustrirovannaja entsiklopedia [Literature and language. A modern illustrated encyclopedia]. Moscow: Rosman.

Palazhchenko, P. (2017). Moj nesistematicheskij slovar'. Iz zapisnoj knizhki perevodchika [My non-systematic dictionary. From the interpreter's notebooks in 2 volumes]. Moscow: RValent. 
Pivoev V. M. (2017). Ironija kak fenomen kul'tury [Irony as a phenomenon of culture]. Moscow/Berlin: Direct-Media.

Pokhodnya, S. I. (1989). Jazykovye vidy i sredstva realizatsii ironii [Verbal types and means of expressing irony]. Kiev: Naukova dumka.

Prokhorov A. M. (ed.) (1997). Bolshoj entsiklopedicheskij slovar [The Large Encyclopedic Dictionary]. Moscow: Bolshaja Rossijskaja Entsiklopedija.

Propp, V. (1976). Problemy komizma $i$ smekha [The Problems of Comic and Laughter]. Moscow: Iskusstvo.

Propp, V. (2009). On the Comic and Laughter. [eds. and transl. by Debbèche, J.-P. \& Perron, P.]. Toronto: University of Toronto Press.

Raskin V. \& Attardo S. (1994). 'Non-literalness and non-bona-fide in language: An approach to formal and computational treatments of humor'. Pragmatics and Cognition 2 (1), pp. 31-69.

Riumina, M. T. (2010). Estetika smekha: Smekh kak virtualnaja realnost [The Aesthetics of Laughter: Laughter as a Virtual reality]. Moscow: Librokom.

Roston, M. (2011). The Comic Mode in English Literature: From the Middle Ages to Today. London / New York: Continuum.

Ruch, W. (2007). 'Foreword and overview. Sense of humor: A new look at an old concept', in Ruch, W. (ed.), The Sense of Humor: Explorations of a Personality Characteristic. Berlin: Mouton de Gruyter, pp. 3-14.

Russian National Corpus (2004-2020). Retrieved on March 27, 2020 from www.ruscorpora.ru.

Shilikhina, K. (2013). 'Canned jokes in Russian public political discourse'. European Journal of Humour Research 1 (2), pp. 84-100.

Shmeleva, E. Y., Shmelev, A. D. (2002). Russkij anekdot: Tekst i rechevoj zhanr [Russian canned joke: a text and a speech genre]. Moscow: Jazyki slavyanskoj kul'tury.

The Russian Science Citation Index (2020). Retrieved 20 March 2020 from www.elibrary.ru.

Ushakov D. N. (ed.) (2006). Tolkovyj slovar' russkogo jazyka [The Explanatory Dictionary of the Russian Language]. Moscow: Alta-Print.

Vasilieva, V. V. (2017). 'Anecdote in professional media text: re-profiling of the speech genre'. Media Linguistics 4 (19), pp. 80-89. Retrieved 25 March 2020 from https://medialing.ru/anekdot-v-professionalnom-mediatekste-pereprofilirovanie-rechevogozhanra.

Verzhinskaya I. V. (2011). 'Jumor: istorija i klassifikatsija ponyatija' [Humour: the history and classification of the concept]. Proceedings of Chelyabinsk State University 11 (226). pp. 2932.

Waterlow, J. (2018). 'It's Only a Joke, Comrade!" Humour, Trust and Everyday Life Under Stalin (1928-1941). Oxford: CreateSpace Independent Publishing Platform. 